\begin{tabular}{|c|c|c|}
\hline B! & $\begin{array}{l}\text { BIODIK: Jurnal IImiah Pendidikan Biologi } \\
\text { ISSN 2580-0922 (online), ISSN 2460-2612 (print) } \\
\text { Volume 07, Nomor 03, Tahun 2021, Hal. 84-92 } \\
\text { Available online at: } \\
\text { https://online-journal.unja.ac.id/biodik }\end{array}$ & BIODIK \\
\hline
\end{tabular}

Research Article

open 2 Access

\title{
Pengembangan Instrumen Penilaian Kinerja Praktikum Biologi Materi Sel Sebagai Unit Terkecil Kehidupan
}

\section{(Development of Performance Assessment Instruments for Biology Practicum Material Cells as the Smallest Unit of Life)}

\author{
Miftahul Jannah*, Afreni Hamidah, Upik Yelianti
}

Magister Pendidikan IPA Universitas Jambi

Alamat: JI.Raden Mattaher No. 16 - Jambi Kode Pos: 36133

${ }^{*}$ Corresponding Authorl: lenaunja2020@gmail.com

\begin{tabular}{|c|c|}
\hline Informasi Artikel & ABSTRACT \\
\hline $\begin{array}{l}\text { Submit: } 30-05-2021 \\
\text { Diterima: } 30-08-2021 \\
\text { Dipublikasikan: } 26-09-2021\end{array}$ & $\begin{array}{l}\text { This research is motivated by the importance of assessment during the } \\
\text { practicum, usually the assessment is carried out only on the practicum report, } \\
\text { not on every process that occurs during the practicum. The purpose of the study } \\
\text { was to determine the stages of developing a practicum performance assessment } \\
\text { instrument on cell material as the smallest unit of life. This type of research uses } \\
\text { research and development, while the development model used adopts the } \\
\text { ADDIE model with five stages, namely: Analysis, Design, Development, } \\
\text { Implementation, and Evaluation. Qualitative data were obtained from the } \\
\text { suggestions of validators of instrument design experts and material experts. The } \\
\text { results of the development of instrument design expert validation were obtained } \\
\text { with a final score of } 73.3 \% \text { with a feasible category. While the material expert } \\
\text { validation obtained a score of } 74.7 \% \text { with a feasible category, and the teacher's } \\
\text { response as an instrument user obtained a score of } 80 \% \text { with a feasible } \\
\text { category, so it can be concluded that the practicum performance assessment } \\
\text { instrument on cell material as the smallest unit of life is feasible to use. } \\
\text { Key words: Performance Assessment Instruments, Cell, Biology }\end{array}$ \\
\hline Penerbit & ABSTRAK \\
\hline $\begin{array}{l}\text { Program Studi Pendidikan Biologi } \\
\text { FKIP Universitas Jambi, } \\
\text { Jambi- Indonesia }\end{array}$ & $\begin{array}{l}\text { Penelitian ini dilatar belakang pentingnya penilaian saat praktikum, biasanya } \\
\text { penilaian dilakukan hanya pada laporan paktikum saja, bukan pada setiap } \\
\text { proses yang terjadi saat praktikum. Tujuan penelitian mengetahui tahapan } \\
\text { pengembangan instrumen penilaian kinerja praktikum pada materi sel sebagai } \\
\text { unit terkecil kehidupan. Jenis penelitian ini menggunakan penelitian } \\
\text { pengembangan (Research and Development), Sedangkan Model } \\
\text { pengembangan yang digunakan mengadopsi model ADDIE dengan lima } \\
\text { tahapan, yaitu: Analisisa (Analysis), Perancangan (Design), Pengembangan } \\
\text { (Development), Implementasi (Implementasi), dan Evaluasi (Evaluate). Data } \\
\text { kualitatif diperoleh dari saran-saran validator ahli desain instrumen dan ahli } \\
\text { materi. Hasil pengembangan validasi ahli desain instrumen diperoleh dengan } \\
\text { skor akhir } 73,3 \% \text { dengan kategori layak. Sedangkan validasi ahli materi } \\
\text { diperoleh skor } 74,7 \% \text { dengan kategori layak, dan respon guru sebagai } \\
\text { pengguna instrumen diperoleh skor } 80 \% \text { dengan kategori baik, sehingga dapat } \\
\text { disimpulkan instrumen penilaian kinerja praktikum pada materi sel sebagai unit } \\
\text { terkecil kehidupan layak untuk digunakan. } \\
\text { Kata Kunci : Instrumen Penilaian kinerja, Sel, Biologi }\end{array}$ \\
\hline
\end{tabular}


This BIODIK : Jurnal IImiah Pendidikan Biologi is licensed under a CC BY-NC-SA (Creative Commons Attribution-ShareAlike 4.0 International License).

\section{PENDAHULUAN}

Praktikum adalah kegiatan belajar mengajar dengan cara tatap muka yang menekankan pada aspek psikomotorik (keterampilan), kognitif (pengetahuan) dan afektif (sikap) dengan menggunakan peralatan di laboratorium/kebun percobaan/lapangan yang terjadwal, kegiatan praktikum dapat membuat siswa menerapkan keterampilan proses sains, serta sikap ilmiah dalam rangka memperoleh pengetahuannya (Subiantoro, 2011).

Menurut Schuler dalam Uno (2012) Penilaian kinerja adalah penilaian berdasarkan hasil pengamatan penilaian terhadap aktivitas siswa sebagaimana yang terjadi. Penilaian dilakukan dengan unjuk kerja, tingkah laku atau interaksi peserta didik. Penerapan pembelajaran berbasis penilai kinerja adalah suatu sistem formal dan struktur yang mengukur, menilai, dan mempengaruhi sifat-sifat yang berkaitan dengan pekerjaan, perilaku, hasil dan juga termasuk kehadiran. Adapun kelebihan penerapan pembelajaran berbasis penilaian kinerja yaitu memberi motivasi yang besar pada peserta didik, serta mendorong aplikasi pembelajaran pada situasi kehidupan yang nyata.

Uno (2012:2) menyatakan Assesment sering pula disebut salah satu bentuk penilaian, sedangkan penilaian merupakan salah satu komponen dalam evaluasi. Ruang lingkup assesment sangat luas dibandingkan dengan evaluasi. Tindakan suatu pengukuran yang bersifat kuantitatif dan penilaian yang bersifat kualitatif adalah merupakan bagian integral yang tidak dapat dipisahkan dari assesment. Arifin dalam Diarta $(2016 ; 65)$ mengemukakan bahwa penilaian merupakan suatu proses atau kegiatan yang sistematis dan berkesinambungan untuk mengumpulkan informasi tentang proses dan hasil belajar peserta didik dalam rangka membuat keputusan-keputusan berdasarkan kriteria pertimbangan tertentu.

Performence Assesment dapat juga digunakan untuk mengukur kinerja nyata yang aktual siswa yang tidak memadai jika diukur hanya dengan mengguanakan tes obyektif. Kecakapan yang dapat dinilai adalah kecakapan dalam membuat laporan. Secara umum assesment dapat diartikan sebagai proses untuk mendapatkan informasi dalam bentuk apapun yang dapat digunakan untuk dasar pengambilan keputusan tentang siswa, baik yang menyangkut kurikulum, program pembelajran, iklim sekolah maupun kebijakan-kebijakan sekolah. Assesment secara sederhana dapat diartikan sebgai proses pengukuran dan nonpengukuran untuk memperoleh data karateristik peserta didik dengan aturan tertentu. Dalam pelaksanakan assesment penbelajaran guru dihadapkan pada tiga istilah yang sering dikacaukan pengertiannya atau bahkan sering pula digunakan secara bersama, yaitu istilah pengukuran, penilaian dan tes.

Selanjutnya dalam penelitian Diartha (2016;) menyatakan bahwa meskipun membutuhkan banyak waktu pada penerapannya instrumen ini menekankan pada pemecahan masalah yang berhubungan dengan konsep kimia, disiplin ilmu lain, bahkan hubungannya dengan realita sehari-hari. Kemudian suryawan $(2015 ;)$ menyatakan instrumen penilaian kinerja berbasis sets valid, efektif dan praktis untuk mengukur keterampilan proses sains. penilaian merupakan suatu proses atau kegiatan yang sistematis dan berkesinambungan untuk mengumpulkan informasi tentang proses dan hasil belajar peserta didik dalam rangka membuat keputusan-keputusan berdasarkan kriteria pertimbangan tertentu.

Berdasarkan uraian di atas, maka dilakukan Pengembangan Media Instrumen penilaian kinerja sebagai salah satu media pembelajaran pada materi sel sebagai unit terkecil kehidupan untuk siswa kelas XI SMA.Sehingga instrumen yang dibuat nantinya mencakup penilaian dari persiapan sebelum praktikum hingga berakhirnya praktikum atau mulai dari pendahuluan hingga pembuatan laporan, karena biasa nya penilaian saat praktikum hanya pada laporan akhir saja, pada persiapan sebelum praktikum dan proses praktikum berlangsung jarang sekali dilakukan penilaian. Maka peneliti melakukan pengembangan instrument penilaian yang di dalamnya mencakup hal yang telah disebutkan sebelumnya. Diharapkan dari instrument tersebut siswa menjadi lebih aktif, karena apapun yang mereka lakukan dari tahap pendahuluan hingga akhir semuanya dinilai. 


\section{METODE PENELITIAN}

Jenis Penelitian ini menggunakan penelitian pengembangan (Research and Development), Pengembangan instrumen penilaian kinerja ini menggunakan model pengembangan ADDIE, Model ADDIE adalah desain model pembelajaran yang sistematis dan terdiri dari 5 tahap meliputi tahap analisa (analyze), desain (design), pengembangan (develop), implementasi (implementation), dan penilaian (evaluate).

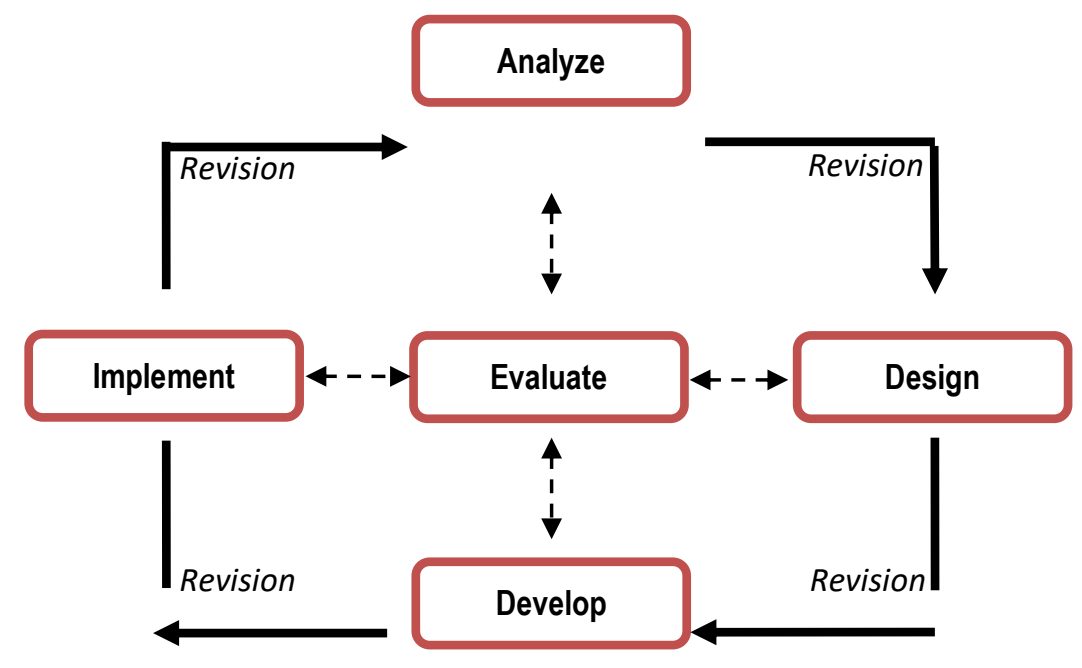

Gambar 1. Model kerangka ADDIE

(Sumber: Rusdi, 2018:17)

Pada tahap analisis ada 4 tahap yang dilakukan pertama analisis kebutuhan merupakan langkah yang dilakukan untuk menentukan kemampuan-kemampuan atau kompetensi yang perlu dipelajari oleh peserta didik untuk meningkatkan efektifitas belajar siswa. Langkah yang dilakukan pada tahap ini juga melalui observasi secara langsung dan observasi dengan cara penyebaran angket kebutuhan pada siswa. Selanjutnya analisis kedua analisis Analisis ini dilakukan untuk menjamin bahwa produk yang dibuat sesuai dengan kondisi ataupun karakteristik siswa yang berhubungan dengan kesulitan yang dialami oleh guru pada saat proses praktikum berlangsung.

Kemudian analisis ketiga analisis materi ini bertujuan untuk menetapkan kebutuhan dalam pengembangan perangkat pembelajaran. Analisis materi ini dapat dilakukan dengan melihat kurikulum yang digunakan di sekolah sehingga materi yang perlu dikembangkangkan berupa media pembelajaran sesuai dengan kompetensi yang harus dikuasai oleh peserta didik dalam belajar biologi dengan melakukan wawancara guru bidang studi Biologi dan penyebaran angket kepada siswa.

Analisi keempat Analisis kebutuhan Guru merupakan langkah yang diperlukan untuk menentukan pemasalahan dan kesalahan yang ada dalam sistem pembelajaran sehingga terjadi penurunan dalam meningkatkan kreatifitas belajar peserta didik. Melalui observasi dengan cara wawancara mendalam kepada guru di SMA Negeri 5 Muaro Jambi, guru SMA Negeri 2 Kota Jambi, dan guru MAN 2 Kota Jambi.Setelah melakukan tahap analisis, maka peneliti melanjutkan ketahap perancangan (design). Pada tahap ini, yang dilakukan adalah membuat rancangan atau desain produk yang akan dibuat, dimulai dengan pembuatan draf kasar berupa storyboard dan menentukan dosen validator.

Tahap pengembangan merupakan tahap dimana spesifikasi desain yang telah dirancang sedemikian rupa diwujudkan dalam bentuk fisik, sehingga tahap ini menghasilkan sebuah produk. Dengan kata lain, tahap pengembangan adalah kegiatan mewujudkan produk yang dihasilkan dalam 
penelitian ini adalah sebuah instrumen penilain kinerja pada materi praktikum sel sebagai unit terkecil kehidupan.

Setelah produk siap, maka produk divalidasi. Validasi dilakukan oleh dua orang ahli yaitu ahli desain instrumen dan ahli materi, guna untuk menilai produk dari aspek desain instrumen dan aspek materi. Sehingga akan diketahui kekurangan ataupun kelemahan dari produk tersebut. Validasi dilakukan secara berkelanjutan hingga diperoleh instrumen penilaian kinerja yang benar-benar baik dan layak untuk dilanjutkan ke tahap implementasi (diuji cobakan).

Setelah instrumen penilaian kinerja divalidasi oleh ahli dan dinyatakan baik dan layak, maka instrumen penilaian kinerja dapat diuji cobakan, tahap inilah yang disebut dengan tahap pelaksanaan (implementation). Uji coba dilakukan untuk mendapatkan tanggapan mengenai produk melalui angket. Ujicoba terdiri atas dua orang guru yaitu: ibu Indaria, S.Pd dan ibu Vera Suhartim, S.Pd yang merupakan guru Biologi SMA Negeri 5 Muaro Jambi. Untuk mengetahui apakah layak atau tidak Instrumen penilaian kinerja yang dikembangkan maka Instrumen perlu memperoleh respon atau tanggapan dari guru yang mengajar mata pelajaran Biologi. Subjek pada tahap ini adalah Guru yang mengajar pelajaran Biologi.

Evaluasi adalah proses untuk melihat apakah media pembelajaran yang sedang dibuat berhasil, sesuai dengan harapan awal atau tidak. Evaluasi dilakukan oleh tim ahli media, desain dan materi untuk mengevaluasi desain dan isi produk. Setelah produk didesain dan dikembangkan oleh pengembang, tahapan selanjutnya adalah mengevaluasi oleh tim ahli yang terdiri atas ahli desain instrumen, dan ahli materi guna mendapatkan saran dan perbaikan terhadap produk. Kemudian produk direvisi sesuai saran dan masukan dari tim ahli desain instrumen dan ahli materi sampai produk dinyatakan baik dan layak untuk diujicobakan. Setelah uji coba dilakukan akan diperoleh respon dari guru yang merupakan evaluasi untuk menghasilkan produk yang lebih baik.

\section{HASIL DAN PEMBAHASAN}

Cover Instrumen penilaian kinerja praktikum didominasi oleh warna hijau dan putih, dengan menggunakan gambar yang menggambarkan kegiatan praktikum mengamati sel. Materi yang digunakan adalah materi sel hewan dan tumbuhan pada kelas XI, selain berisi penilaian kinerja siswa, instrumen ini juga dilengkapi materi bergambar yang mendukung kegiatan praktikum agar siswa dapat dengan mudah memahami kegiatan praktikum.

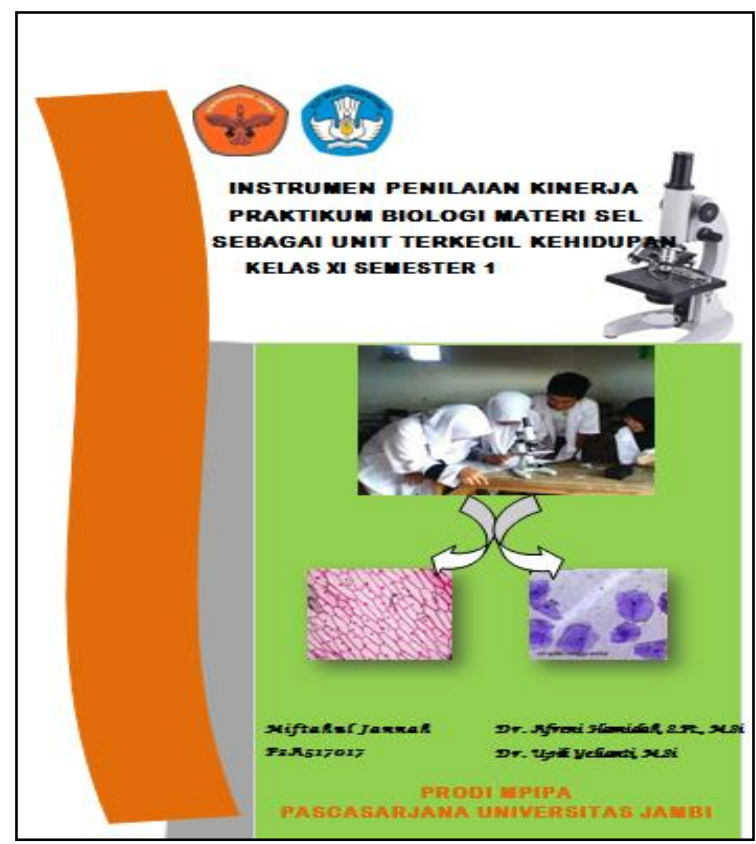

Gambar 1. Cover Instrumen Penilaian Kinerja

(Sumber : Dokumentasi pribadi; Jannah: 2019) 
Penyusunan materi berdsarkan $\mathrm{KI}, \mathrm{KD}$ dan indikator. Jenis huruf yang digunakan adalah Cambria dan Times New Roman, ukuran huruf yang digunakan bervariasi, 12 dan 14.

Tabel.2 Hasil respon guru terhadap instrument penilaian kinerja

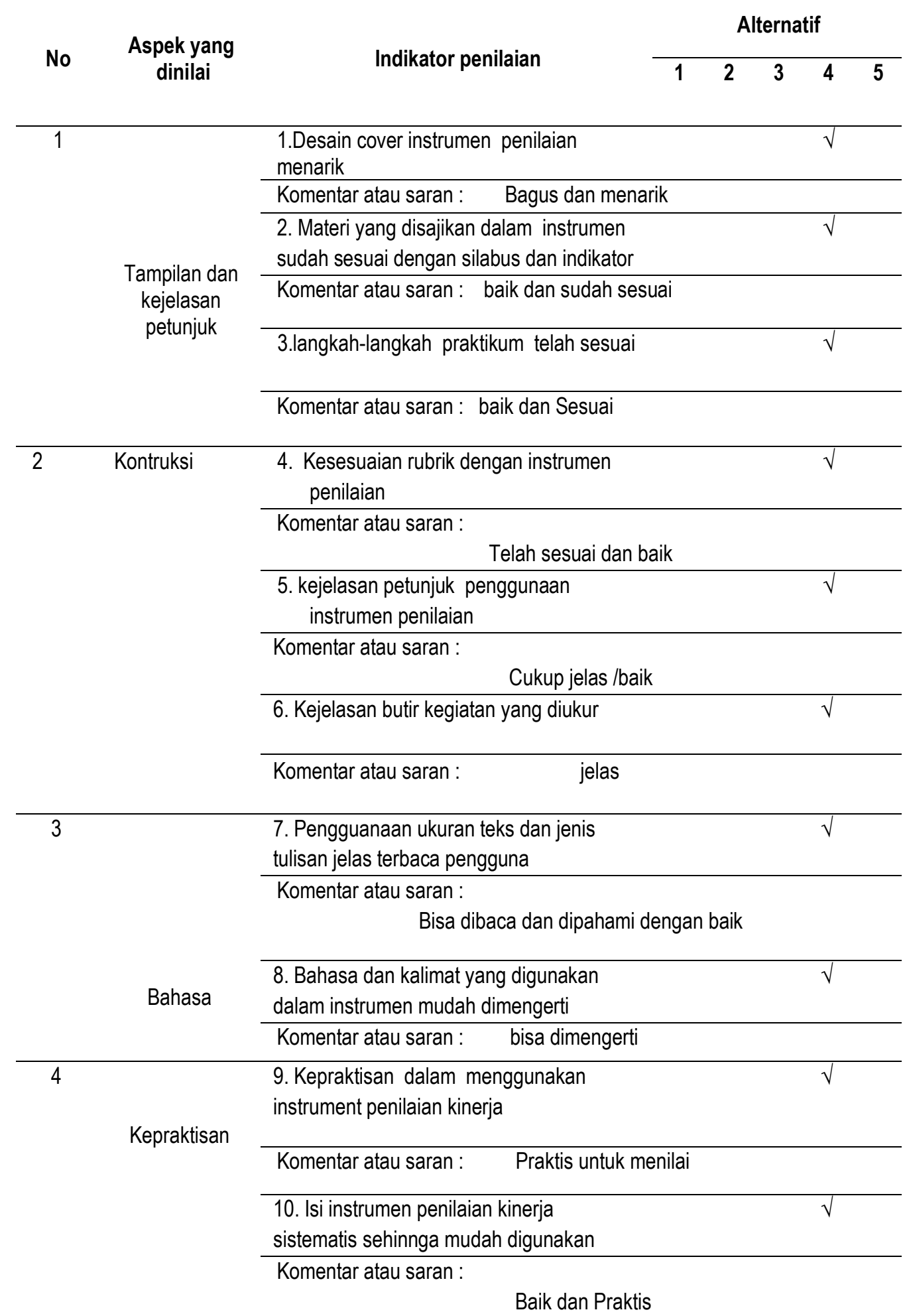


Dari tabel 1 diketahui bahwa respon guru dalam menggunakan instrumen penilaian kinerja memiliki nilai 4 pada setiap item, yang menunjukkan kategori baik. Oleh karena itu, dapat disimpulkan bahwa penggunaan menggunakan instrumen penilaian kinerja efektif digunakan dalam praktikum biologi.

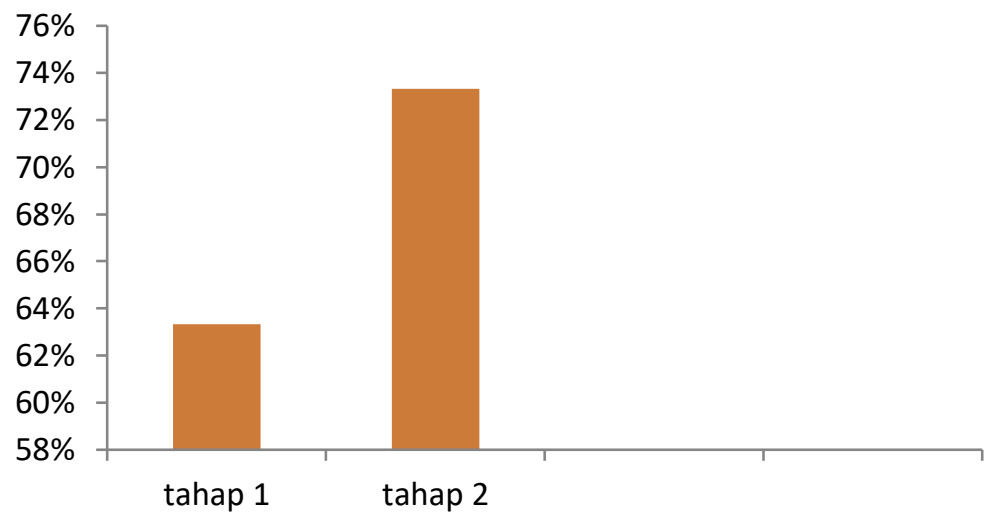

Gambar 2. Persentasi validasi ahli desain instrumen

Berdasarkan gambar 2 dapat diketahui bahwa validasi ahli materi dilakukan sebnyak tiga kali.Validasi tahap pertama tidak diperoleh skor, karena angke belum digunakan, dilanjutkan validasi tahap ke dua dengan nilai persentase $63,33 \%$ dengan kategori cukup layak, namu masih ada komentar dan saran yang harus diperbaiki sehingga validasi dilanjutkan pada tahap ketiga. Validasi tahap ketiga memperoleh nilai persentase $73,33 \%$ dengan kategori layak, sehingga instrumen penilaian kinerja praktikum yang dikembangkan sudah layak diujicobakan.

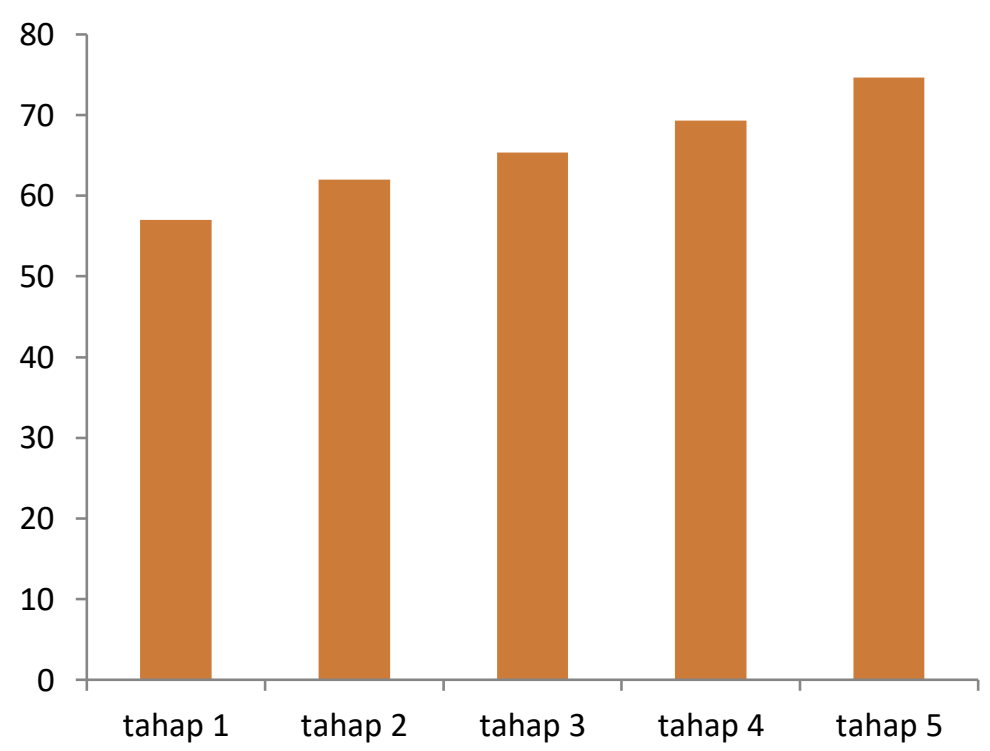

Gambar 3 Respon Ahli materi

Berdasarkan gambar 3 dapat diketahui bahwa validasi ahli materi dilakukan sebnyak lima kali. Validasi tahap pertama memperoleh persentase 57,33 , dilanjutkan validasi tahap ke dua dengan nilai persentase $62,67 \%$ dengan kategori valid, namu masih ada komentar dan saran yang harus diperbaiki sehingga validasi dilanjutkan pada tahap ketiga. Validasi tahap ketiga memperoleh nilai persentase $65,33 \%$ dengan kategori sangat valid, walaupun kategori yang didapat sudah sangat valid, tetapi skornya belum sesuai yang diharapkan, maka dilanjutkan dengan validasi tahap 4 dengan persentasi $69,33 \%$ dan 
tahap kelima persentasi $74,67 \%$ dengan katagori sangat valid sehingga instrumen penilaian kinerja praktikum yang dikembangkan sudah layak untuk diujicobakan.

\section{Respon Guru}

Berdasarkan hasil respon guru menunjukkan bahwa instrumen penilaian kinerja praktikum memperoleh nilai rata-rata keseluruhan $80 \%$ dengan kategori baik. Indikator penilaian dalam respon guru ada empat aspek yaitu kejelasan petunjuk, kontruksi, bahasa, dan kepraktisan. Hasil respon guru terhadap empat aspek dapat dilihat pada gambar 4.

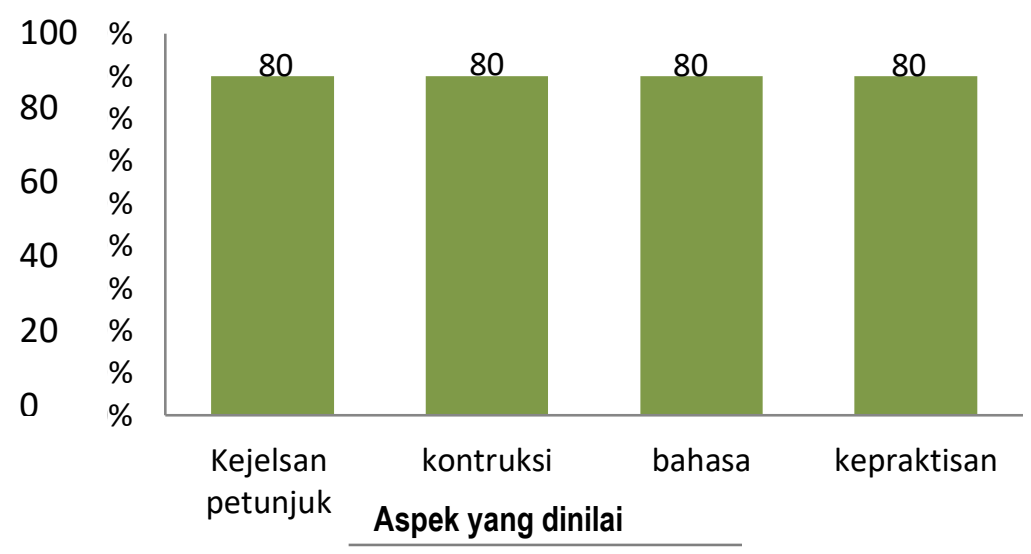

Gambar 4. Respon guru Berdasarkan beberapa aspek

Pengembangan Instrumen penilaian kinerja praktikum untuk kelas XI materi sel sebagai unit terkecil kehidupan memperoleh nilai persentase $80 \%$ pada setiap aspek yaitu kejelasan petunjuk, kontruksi, bahasa, dan kepraktisan. Hal ini dikarenakan Instrumen penilaian kinerja praktikum yang dikembangkan menggunakan desain cover dan tampilan yang menarik, bahasa yang digunakan sederhana dan sesuai EYD, materi yang disajikan sesuai dengan $\mathrm{KI}, \mathrm{KD}$ dan tujuan pembelajaran.

Penilaian unjuk kerja (performance assessment) dapat melihat perkembangan siswa dalam mempelajari materi yang diberikan karena dilakukan oleh siswa dalam sebuah unjuk kerja. Unjuk kerja yang dilakukan oleh siswa diamati oleh guru. Siswa yang bersangkutan diharapkan mengetahui perkembangan kemampuannya dalam menyelesaikan suatu tugas tertentu. Siswa termotivasi untuk memperbaiki kekurangan dan meningkatkan terus kemampuan yang dimilikinya. Penerapan performance assessment dalam kegiatan pembelajaran di laboratorium menjadikan siswa lebih aktif. Keterlibatan dan keaktifan dalam pembelajaran akan lebih memotivasi peserta didik dalam memahami materi pembelajaran yang dipraktikumkan. Instrumen penilaian kinerja harus mencakup seluruh kompetensi setiap percobaan, sehingga kompetensi peserta didik secara individu dan kelompok dapat terukur (Kusumaningtyas et al., 2018). Instrumen penilaian kinerja dapat meningkatkan kemampuan inquiry siswa melalui observasi dan eksperimen (Kusumastuti et al., 2020). Instrumen penilaian kinerja juga dapat digunakan untuk mengukur sikap tanggung jawab peserta didik (Azzizzah \& Supahar, 2021).

\section{SIMPULAN}

Berdasarkan hasil penelitian dan pembahasan dapat disimpulkan bahwa Pengembangan Instrumen Penilaian kinerja pada materi sel sebagai unit terkecil kehidupan untuk kelas XI MIPA dilakukan melalui dua kali validasi ahli desain instrumen dengan skor akhir 55 persentase $73,33 \%$ kategori sangat 
layak dan lima kali validasi materi dengan skor akhir 56 persentase 74,7\% kategori sangat layak. Sedangkan Respon guru terhadap instrumen penilaian kinerja praktikum ini memperoleh skor 80 dengan kategori baik. Secara teoritis hasil validasi materi dan hasil validasi desain instrumen terhadap produk yang dikembangkan dinyatakan layak untuk digunakan. Produk penelitian ini berupa instrumen penilaian unjuk kerja, yang dilengkapi kisi-kisi penilaian serta rubrik penilaian dengan menggunakan skor 5 .

\section{UCAPAN TERIMA KASIH}

Dalam proses penyusunan hingga terselesaikannya tesis ini tidak terlepas dari bimbingan, arahan dan bantuan dari berbagai pihak, untuk itu penulis mengucapkan terima kasih yang sebesarbesarnya terutama kepada yang terhormat Ibu Dr. Afreni Hamidah, S.Pt,.M.Si selaku pembimbing I, Ibu Dr. Upik Yelianti, M.S selaku pembimbing II, yang telah membimbing dan memotivasi penulis selama proses penyelesaian tesis ini. Tak lupa pula penulis mengucapkan terima kasih kepada yang terhormat: Rektor Universitas Jambi dan Direktur Program Pascasarjana Universitas Jambi. Bapak Prof. Dr. Tedjo Sukmono,S.Si, M.Si selaku penguji I dan Ibu Dr. Yusnaidar, S.Si, M.Si selaku penguji II. Bapak Dr. Agus Subagyo, S.Si., M.Si selaku sekretaris program studi Magister Pendidikan IImu Pengetahuan Alam Universitas Jambi. Ibu Si Dr. Revis Asra, S.Si, M.Si selaku validator materi dan Ibu Dr. Risnita, M.Pd selaku validator media. Bapak dan Ibu dosen khususnya dosen program Studi Magister Pendidikan IImu Pengetahuan Alam yang telah banyak memberikan ilmu kepada penulis selama mengikuti pendidikan di Program Pascasarjana Universitas Jambi. Bapak Dr. Zamroni, M.Pd.I selaku kepala SMA N 5 Muaro Jambi yang telah memberikan izin untuk melakukan penelitian dan Ibu Vera Suhartim, S.Pd dan Ibu Indaria, S.Pd selaku guru Biologi dan responden di SMA Negeri 5 Muaro Jambi, Siswa-siswi kelas XI SMA Negeri 5 Muaro Jambi yang telah membantu sebagai responden dalam penyelesaian tesis ini. Kedua orang tua tercinta Ayahanda Muhtar dan ibunda Ismatun, serta suami Rd. Rahman Hambali, yang telah memberikan do'a, semangat, dukungan dan dari tetes keringat merekalah tesis ini dapat terselesaikan dengan baik. Teman-teman seperjuangan pada program magister pendidikan IPA Pascasarjana Universitas Jambi yang telah membantu dan memberikan dukungan dalam menyelesaikan tesis ini. Semua pihak yang tidak dapat penulis sebutkan satu per satu yang telah memberikan bantuan berupa moril dan materil kepada penulis. Semoga Allah SWT memberikan limpahan rahmat dan karuniaNya serta dapat menjadi amal jariah yang bernilai ibadah atas kebaikan semua pihak yang terlibat dalam proses penyelesaian tesis ini. Akhirnya penulis menyadari bahwa dalam penyususnan tesis ini masih terdapat banyak kekurangan, namun penulis berharap tesis ini dapat bermanfaat sebagai pedoman pelaksanaan penelitian bagi peneliti maupun sebagai sumber ilmu pengetahuan bagi para pembaca. 


\section{RUJUKAN}

Azzizzah, F. A., \& Supahar, S. (2021). Penilaian kinerja untuk mengukur sikap tanggung jawab peserta didik. Measurement in Educational Research, 1(1), 1-11.

https://doi.org/http://dx.doi.org/10.33292/meter.v1i1.106

Diartha, N, I., Wildan, W., \& Muntari, M. (2016). Penilaian Kinerja (Performance Assessment) Dalam Pembelajaran Kimia. Jurnal Pijar Mipa, 11(1).

http://jurnalfkip.unram.ac.id/index.php/JPM/article/view/64.

Febrianty D, (2017). Pengembangan intrument berbasis kinerja praktikum organisai kehidupan berbasis kontruktivisme kelas VII SMP. Program Studi Magister pendidikan IPA. Universitas Jambi : Jambi.

Kurniawati, M, D., (2017) pengembangan intrument penilaian berbasis kinerja pada pembelajaran tematik siswa kelas IV sekolah dasar. Program Studi Magister Keguruan Guru Sd. Universitas Lampung : Bandar Lampung.

Kusumaningtyas, P., Yusvitasari, R. E., \& Majid, A. (2018). Pengembangan Instrumen Penilaian Kinerja Untuk Mengukur Kompetensi Siswa Dalam Kegiatan Praktikum Kimia Di Sma/K. Jurnal Inovasi Pendidikan Kimia, 12(2).

Kusumastuti, I., Anggraeni, S., \& Surakusumah, W. (2020). Penerapan Asesmen Kinerja Dalam Meningkatkan Kemampuan Inkuiri Melalui Pembelajaran Levels Of Inquiry Siswa SMA. Syntax Literate; Jurnal IImiah Indonesia, 5(1), 101-116. https://doi.org/http://dx.doi.org/10.36418/syntaxliterate.v5i1.860

Subiantoro, A.W. (2011). Keselamatan dan Kesehatan Kerja di Laboratorium Sains. Materi disampaikan pada Pelatihan Pengelolaan Laboratorium Sains Sekolah bagi guru-guru sains SMP/MTs Kabupaten Temanggung, di FMIPA UNY, Oktober 2011.

Sugiyono. 2013. Metode Penelitian Kuantitatif Kualitatif Dan R \& D. Bandung: Alfabeta.

Sugiono . 2017. Metode Penelitian Kuantitatif Kualitatif Dan R \& D. Bandung: Alfabeta.

Suryawan, A., Binadja, A., \& Sulistyorini, S. (2015). Pengembangan Instrumen Performance Assessment Praktikum Bervisi Sets Untuk Mengukur Keterampilan Proses Sains. Journal Of Primary Education, 4(1). https://journal.unnes.ac.id/sju/index.php/jpe/article/view/6915.Diakses 13 Februari

Uno H. B.. \& Satria K. (2012). Assesment Pembelajaran. Jakarta: PT. Bumi Aksara 